Short Communication

\title{
Corrosion Behavior of ASTM A615 Steel Rebars Embedded in Concrete with Ceramic Waste Dustas a Partial Replacement of Portland Cement
}

\author{
Xiaojuan Lv \\ Institute of civil engineering, Huanghuai University,Zhumadian, Henan 463000, china \\ E-mail:xiaojuanlv2000@sina.com and20070905@ huanghuai.edu.cn
}

doi: $10.20964 / 2020.08 .36$

Received: 2 March 2020/ Accepted: 8 May 2020 / Published: 10 July 2020

In the present investigation, the effect of ceramic waste dust (CWD) as a partial replacement of Portland cement (PC) on the corrosion behavior of ASTM A615 steel rebarwere evaluated byelectrochemical impedance spectroscopy (EIS), open circuit potential (OCP) andwater absorption tests after exposure to the marine environment. All samples with CWDs show a decrease in water absorption with increasing exposure time compared to the PC concrete. The samples with 15\% CWD revealed the highest compressive strength during theentire exposure time in $3.5 \mathrm{wt} \% \mathrm{NaCl}$ solution. The OCP value of the reinforced concrete samples with $15 \mathrm{wt} \%$ CWDs stayedin the low or uncertain corrosion area for much longer. The surface morphologies of carbon steel rebarsindicatedthat the amount of pitting corrosion on the steel bar embedded in $15 \mathrm{wt} \%$ CWD concrete sample was significantly lower than that of the others. The electrochemical results showedthat the higher content of CWDs up to $15 \mathrm{wt} \%$ in PC has significantly improved the concrete structure as well as reduced corrosion rate.

Keywords: Ceramic waste dust; Partial replacement of Portland cement; Corrosion resistance; Carbon steel rebar; Electrochemical technique

\section{FULL TEXT}

(C) 2020 The Authors. Published by ESG (www.electrochemsci.org). This article is an open access article distributed under the terms and conditions of the Creative Commons Attribution license (http://creativecommons.org 